\title{
A siker tényezői: Győr példáján egy kutatással és monográfia-sorozatával összefüggésben, különös tekintettel Honvári J. (szerk.): Győr fejlődésének mozgatórugói c. monográfiájára (Universitas-Győr Nonprofit Kft., Győr, 2014. 236 o.)
}

\author{
KISS ÉVA
}

\begin{abstract}
KISS Éva: tudományos tanácsadó, MTA Csillagászati és Földtudományi Kutatóközpont, Földrajztudományi Intézet, Budapest; kiss.eva@csfk.mta.hu
\end{abstract}

Éva KISS: scientific advisor, Geographical Institute, Research Centre for Astronomy and Earth Sciences, Hungarian Academy of Sciences, Budapest; kiss.eva@csfk.mta.hu

A recenzió általában egy könyvhöz kapcsolódó gondolatok, vélemények ismertetése szokott lenni. Az, hogy most mégis kissé eltérek ettől, alapvetően annak tulajdonítható, hogy a bemutatásra kerülol kötet, amely egy monográfia-sorozat második része, tartalmilag szorosan kapcsolódik a továbbiakhoz, mintegy „bevezeti” azokat. A monográfia-sorozat tagjai a közelmúltban jelentek meg A Győri Járműipari Körzet, mint a térségi fejlesztés új iránya és eszköze c. kutatás keretében, az Universitas-Győr Nonprofit Kft. gondozásában. A hat monográfia sorrendben a következő:

- Rechnitzer János, Tamándl László (szerk.) (2014): A Győri Járműipari Körzet, mint a térségi fejlesztés új iránya és eszköze (Nyitókiadvány, 70 o.);

- Honvári János (szerk.) (2014): Győr fejlődésének mozgatórugói (236 o.);

- Hardi Tamás, Somlyódyné Pfeil Edit (szerk.) (2014): Városfejlődési trendek és állami szerepek (234 o.);

- Dusek Tamás (szerk.) (2014): A városi rendszer müködése (236 o.);

- Csizmadia Zoltán, Tóth Péter (szerk.) (2014): A helyi társadalom és intézményrendszer Győrben (308 o.);

- Lados Mihály (szerk.) (2014): A gazdaságszerkezet és vonzáskörzet alakulása (280 o.).

Mindegyik könyv szerkesztett kiadvány, jelentős szerzői gárdával, akik között nemcsak a győri mühelyek (MTA Közgazdaság- és Regionális Tudományi Kutatóközpont Nyugat-magyarországi Tudományos Osztálya és a Széchenyi István Egyetem) jeles képviselői, hanem más intézmények (például a Debreceni Egyetem, a Szlovák Tudományos Akadémia) munkatársai is megtalálhatók. A kötetek

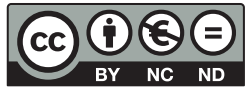


szerkezetileg nem egységesek és a bennük levő tanulmányok száma, hossza és tartalmi színvonala is igen változó. A nyitókiadvány abból a szempontból kivétel, hogy nem tanulmányokat tartalmaz, hanem a projekt céljait és feladatait, valamint főbb eredményeit sorolja fel, amit a gazdag publikációs lista is tanúsít. A témaválasztást két okkal - Győr járműiparban betöltött kimagasló szerepével és a városrégiók jelentőségének felértékelődésével - indokolta a kutatás vezetője, Rechnitzer János. Ez a nagy ívü kutatás öt elméleti és kilenc empirikus fő irányt fogott össze, amelyek mint kutatási résztémák szolgáltatták az egyes monográfiák témaköreit.

A sorozat öt további kötete egy témát, pontosabban Győrt vizsgálja másmás aspektusból, szűkebb és tágabb környezetében egyaránt, s arra a kérdésre keresi a választ, hogy milyen tényezők és milyen mértékben játszottak szerepet Győr fejlődésében, elért gazdasági eredményeiben. Másképpen fogalmazva - ahogy a második kötet címe is jelzi -, hogy melyek Győr fejlődésének mozgatórugói, és hogy miért tekinthető igazi sikernek a város eddigi „életútja”. A választ az egyes kötetek különböző témák (például nemzetközi beágyazódás, külső kapcsolatok, állami szerepek, helyi társadalom, intézményhálózat, vonzáskörzet) köré szerveződött tanulmányai együttesen adják meg. Az írások ugyanis valamilyen részszempontból kísérelnek meg feleletet adni arra, hogy mi tette lehetővé a város fejlődését. A tanulmányok nagy száma és az öt kötet is azt sugallja, hogy a válasz bonyolult, és hogy egy település sikere sok tényező függvénye.

Napjainkig idehaza is számos írás született (például Bakti 2002; Baranyi 2000; Mezeyné Varju 1998; Timár, Velkey 2003; Váradi 1997) a sikeres vagy sikeresnek vélt településekről (például Budaörs, Gödöllő, Mátészalka, Solymár, Székesfehérvár, Szentgotthárd), amelyek nagyobb hányadát városok képezik. Ez nyilván nem véletlen, mivel a települések közül rendszerint a városok reagálnak gyorsabban és látványosabban a változásokra. De azzal is magyarázható, hogy a 20. század vége felé a globalizáció előrehaladásával az országok helyett a városok jelentősége nőtt meg, amelyek között a verseny mind jobban kiéleződik. A posztszocialista városok a rendszerváltozás következtében új helyzettel kerültek szembe: egyfelől gyökeres politikai, gazdasági és társadalmi változásokon mentek át, másfelől, ezzel egyidejűleg a fokozódó nemzetközi versenyben is helyt kell(ett) állniuk. Már nemcsak országon belül, hanem a világ városaival, városrégióival kell(ett) „felvenniük a versenyt”. Az erre való ráébredés szintén arra ösztönözte a városokat, hogy számba vegyék adottságaikat, amelyeknek a szocializmusban nem nagyon tulajdonítottak különösebb jelentőséget. A kapitalizmus viszont sikerorientált, és a sikerhez rendkívül fontos a lokális erőforrások alapos ismerete. Ez a cél vezérelte bizonyos fokig a projekt résztvevőit is.

Az utóbbi évtizedekben a hazai szakirodalomban - legalábbis a geográfia és a regionális tudomány terén - még olyan több kötetes „tanulmánygyüjtemények" nem láttak napvilágot egyetlen vidéki városunkról sem, mint amilyen a Rába-parti városról készült 2014-ben. Indokolható ez azzal is, hogy városaink (2014-ben 348 volt) közül Budapest után Győr fejlődik a legdinamikusabban és a 
legtartósabban. E fejlődés okára próbálnak magyarázatot adni az egyes kötetek tanulmányai, amelyekben az Enyedi György által leírt sikeres város tényezői (gazdasági szerkezetváltoztatás képessége, magas hozzáadottérték-arány a szolgáltatásokban, tudásalapú termelés, erős innovációs képesség, stratégiai tervezés, növekvő jövedelem és foglalkoztatás, jelentős külső kapcsolatok stb.) is visszaköszönnek (Enyedi 1997). Sőt, a siker faktorai „finomulnak” és további részletekkel gazdagodnak Győr példája révén, miközben a város sikerének „titkai” is mind jobban feltárulnak az olvasó előtt.

A monográfia-sorozat második része alapvetően történeti aspektusból keresi a gazdasági siker okait, a gazdasági fejlődés mozgatórugóit. A gyökerek, a múlt kutatása azért is fontos, mert erre épül a jelen, amely a jövő alapja. A gazdasági siker csak az egyik azon tényezők közül, amelyek egy város sikeréhez szükségesek, és hogy mi minden kell még egy város, egy gazdaság sikeréhez (például a lakóhelyhez való kötődés, identitástudat, bizalom, vállalati nyitottság, sajátos társadalmi rétegződés, együttmüködő képesség stb.), ahhoz a többi monográfia szolgáltat további adalékokat. Az pedig, hogy miért ez a könyv a részletesebb recenzió tárgya, annak a már említetteken kívül az az oka, hogy a recenzens érdeklődéséhez e kötet írásai kapcsolódnak a legszorosabban.

A szerkesztő, Honvári János a kiadvány bevezetőjében röviden áttekinti Győr fejlődését: egyrészt hogy hogyan lett a „kalmárvárosból iparváros”, másrészt hogy hogyan lett a középkorban még jelentéktelen városból a 19. század végére, a 20 . század elejére az ország egyik, majd a 21. század elejére az ország legfontosabb vidéki ipari centruma. Az okok közül is említ néhányat: például a fegyelmezett munkaerőt, a város ipart támogató politikáját, és azt, hogy a város mindig alkalmazkodott a megváltozott feltételekhez. Az ipar fejlődése ugyanis nem volt töretlen, hanem megtorpanásokkal, visszaesésekkel tarkított, amelyekből mindig sikeresen, megújulva került ki Győr. Ebben nagy szerepet játszottak fontosabb ipari létesítményei, amelyek mindig tudtak alkalmazkodni az új körülményekhez. Napjainkra a legnagyobb jelentőségre az Audi tett szert, amely „tartós jelenlétre rendezkedett be”. A nagy befektető letelepülése sok szempontból előnyös a városnak, azonban azt is jól látja a szerző, hogy komoly veszélyt is hordoz. Úgy véli, hogy mivel a város nem egy „alulról jövő kezdeményezés” eredőjeként jutott el a mostani pozícióba, hanem egy „kívülről” érkezett külföldi befektető hatására, ezért „nem biztos, hogy elég erős ahhoz, hogy nagyobb zökkenők nélkül túlélje a nagyvállalat esetleges továbbállását". S mivel általa szinte mindent „készen megkapott” a város, ezért el is kényelmesedhet annak az útnak a keresésétől, „kitalálásától”, amely tartós fejlődését megalapozza. De az is lehetséges, hogy ennek a projektnek az eredményei elősegítik az „új út” meghatározását, vagy legalább közelebb visznek hozzá.

Jakab Petra Sikeres gazdasági modellváltások Győrben c. tanulmánya szintén a város történelmét tekinti át, a hangsúlyt a település történelmi modellváltásaira, kiváltképp a 20. század közepétől napjainkig tartó fejlődésre helyezve. Azokat az aktorokat és faktorokat keresi, amelyek meghatározták és 
most is meghatározzák a kisalföldi város gazdaságának múltját, jelenét és jövőjét. Rámutatott arra, hogy a modellváltásban mindig nagy szerepe volt a helyi társadalom milyenségének (például mentalitásának, szorgalmának, munkához való viszonyának). Különösen a német ajkú lakosságnak tulajdonít nagy érdemeket, akik nyitottá és befogadóvá tették a települést, valamint a helyi vezetőknek (polgármestereknek), akik tudatos iparpolitikával segítették a helyi ipar fejlődését. Az emberi tényező, illetve a helyi vezetés milyenségének fontosságát a települések sikerében már több kutatás feltárta (például Kiss 1992; Ludescher 2009; Váradi 1997). Ugyanakkor azt is megjegyzi a szerző, hogy a sikeres váltáshoz más tényezőkre is szükség volt (például kedvező földrajzi fekvés és közlekedés-földrajzi helyzet, az oktatás és képzés magas szintje, tradíciók), amelyek nemcsak a 19. században, hanem a 20. század végén is sikeres alkalmazkodást tettek lehetővé. Hozzájárultak nagynevü vállalatok (például az Audi) megtelepedéséhez és az ipar, elsősorban a járműipar újbóli felvirágzásához, ami miatt találóan akár „Audistadt”-nak is nevezhető Győr városa.

A város vezető ipari ágazata a közúti járműgyártás, amely több mint száz éves múltra tekint vissza. Az 1896-ban alapított Rába Magyar Vagon- és Gépgyár története lényegében azonos a közúti jármügyártás történetével. Germuska Pál és Honvári János közel száz oldalban, részletesen foglalja össze a gyár életének minden mozzanatát. A rendszerváltozás idejére szinte végnapjait élő vállalat az 1990-es években markáns (szervezeti, strukturális, műszaki-technológiai) változások színtere volt. Kiterjedt nemzetközi kapcsolatrendszere, amelyet Áldozó István elemez, szintén átalakult. A széles körű külföldi piaci kapcsolatok azért is említésre érdemesek, mert kevés olyan vállalat volt hazánkban a szocializmus évtizedeiben, amely neve az USA-ban, Nyugat-Európában és Ázsiában egyaránt ismert volt, ami előnyt jelentett 1989 után. A magyar járműipar zászlóshajójának tekintett vállalat fennmaradásához és sikeres alkalmazkodásához nagyban hozzájárult diverzifikált kapcsolatrendszere, amelyre mindig nagy figyelmet fordított a vállalat életében hosszú időn át kiemelkedő szerepet játszott és elévülhetetlen érdemeket szerzett egykori vezér, Horváth Ede. Vezetése alatt készült el az az óriási, 114 ezer m²$^{2}$-es csarnok, amelyet később az Audi vásárolt meg, s ezzel megalapozta a közúti járműgyártás jövőjét Győrben. A csarnok nélkül valószínűleg jóval kisebb esélye lett volna a városnak a német cég akkori telephely-választási döntésében.

Győr iparában a gépipar mellett évtizedeken át kiemelt helyet foglalt el a textilipar is, amelynek történeti feldolgozására Orbánné Horváth Márta vállalkozott. Az első textilüzemet 1900-ban hozták létre, amelyhez a későbbiekben újabbak csatlakoztak. A hat textilgyárból mára már csak kettő (Glovita, Graboplast) maradt fenn, eltérő fejlődési utakat járva be 1989 után. A Graboplast teljes profilváltást hajtott végre és a műbőrgyárból műanyagpadló-előállítóvá vált. A Glovita szükítette termékskáláját, és ma az egyik legismertebb kesztyügyár Európában. Száz év alatt tehát „nagyot fordult a világ” a győri textiliparban. Az egykor virágzó és a lokális gazdaságban kitüntetett helyet elfoglalt ágazat szá- 
mottevően összezsugorodott. Ez nemcsak a rendszerváltozás utáni radikális változások következménye, hanem sokkal inkább a világ textiliparában lezajlott nagyarányú térbeli átrendeződéseké. A textilipar már évtizedek óta a hanyatló ágazatok közé sorolható a fejlett országokban. A termelést az olcsó munkaerővel rendelkező országokba helyezték át, s csak a tervezés, az egyedi, nagy értékủ termékek gyártása és a tudásigényesebb, kvalifikáltabb munkaerőt igénylő munkafázisok maradtak meg a centrumországokban. Arra a kérdésre, hogy van-e jövője a győri textiliparnak, a szerző nem ad határozott választ, sejthető azonban, hogy az egykor sikeres ágazatnak a jövőben is lehet létjogosultsága. Ahhoz viszont elengedhetetlen a szakemberképzés fejlesztése, kiváló minőségű termékek előállítása és a folyamatos alkalmazkodás az új feltételekhez.

A győri ipar fejlődése és sikeressége nagymértékben betudható a helyi emberi erőforrás kiváló minőségének, a különböző oktatási intézményeknek, a kulturális és művészeti élet sokszínűségének, az egészségügyi és szociális ellátóintézmények kiépítettségének, továbbá a lakosság sport iránti rajongásából fakadó gazdag sportolási lehetőségeknek. Győrben már a szocializmus időszakában is törekedtek a munkaerő tudását, képzettségét, egészségi állapotát és általános jólétét segítő intézményi struktúra kiépítésére, és 1989 után is nagy volumenű fejlesztések valósultak meg, amelynek részleteit, mint a siker újabb tényezőit Gecsényi Lajos tárja fel. A város, illetve a helyi vállalatok vezetése hamar felismerte, hogy a munkaerőbe érdemes ily módon is „befektetni”, mert a gazdaság, az ipar csak így lehet sikeres, ezért támogatták a helyi vállalatok a különböző intézmények működését és fejlesztését. Ráadásul ez az elköteleződés és hagyomány a rendszerváltozás után is érvényesült, az azóta létesült vállalatok is nagy figyelmet fordítanak a munkaerő minőségének és életkörülményeinek kedvezőbbé tételére.

Már a Rába esetében is kitűnt, hogy a vezető kvalitásai, személyes adottságai jelentősen hozzájárulnak egy-egy vállalat sorsának alakulásához. Éppen ezért merülhetett fel az a kérdés, hogy melyek azok a sajátos jellemvonások - ha vannak ilyenek egyáltalán -, amelyek a győri gazdasági vezetőket jellemezték a szocializmus évtizedeiben. A szerző, Varga Balázs, több győri szocialista nagyvállalati vezető életútját nyomon követve - közös vonásként - kiemeli, hogy nem voltak győri születésűek, hogy technikus volt legmagasabb iskolai végzettségük, és hogy koruk „emblematikus figurái” voltak. De hogy „pont miért belőlük lett a gazdasági élet meghatározó szereplője a Kádár-korszakban", arra nem kapunk egyértelmű választ. Szükség van tehát a szerző által is jelzett további kutatásokra a kérdés minél pontosabb megválaszolásához. A bemutatott demográfiai, társadalmi ismérvek és különféle minősítések, véleményezések tükrében feltételezheto, hogy elsősorban az örökölt, „hozott adottságoknak” (jó vezetői érzék, határozottság, szorgalom, igényesség stb.) tudható be, hogy szerény iskolázottsági hátterük ellenére is igen eredményesen tudtak vezetni egy-egy nagyvállalatot. A jó vállalati vezetők ugyancsak meghatározó sikerfaktorok a város életében, mivel a vállalat sikere a helyi gazdaság sikere, az pedig egyben a város sikere. 
A könyv utolsó tanulmánya, amely egy összevetésre tesz kísérletet Trencsén és Győr között, akár kakukktojásnak is vélhető. Hacsak Győr sikere és Horbulák Zsolt írásának a témához való illeszkedése azokra a "távirati stílusban” felsorolt hasonlóságokra és különbségekre nem vezethető vissza, amelyek az utolsó oldalakon találhatók. Különösen a különbségekről érdemes szólni, mert azoknak köszönhető a szerző szerint, hogy Győr „előrébb jár” és sikeresebb, mint Trencsén. A fö különbségek közé sorolja a lakosságszámon és a felsőfokú intézmények megjelenésének időpontján túl, hogy Győrnek például van szlovák nyelvű honlapja, amit földrajzi fekvésével indokol, de az bizonyára a szlovák munkaerő győri jelenlétével is összefügg. Továbbá, hogy a városon belül kiterjedt és jól működő kapcsolatok vannak a városvezetők, a különböző gazdasági szereplők és az oktatási és kutatási intézmények között, míg Trencsénben ez nem jellemző. A szlovák város egyeteme csak most kezdi kialakítani nemzetközi kapcsolatait, szemben Győrrel, amely már évek óta több szlovák felsőfokú intézménnyel is jó kapcsolatokat ápol. Mindezekből következik, hogy a nyitottság és a jó kommunikációs képesség szintén a siker fontos tényezői.

Összességében elfogadható a könyv hátsó borítóján olvasható végkövetkeztetés, hogy Győr fejlődése, gazdasági sikerei elsődlegesen a külső tényezőknek és a város jó alkalmazkodóképességének köszönhető. Azt ugyanakkor hangsúlyozni kell, hogy Győr kedvező adottságai, előnyös endogén tényezői (például az ipari tradíciók, a történelmi örökség, társadalmi tényezők) nélkül nem érte volna el azokat az eredményeket, amelyek ma jellemzik. A jó „indulási feltételek” tehát a helyi gazdaság és a város sikerének alapvető feltételei (voltak). A „győri modell” példaként szolgálhat más városok számára is, bár hasonlóan jó lokális adottságok híján aligha követhető. A kötet(ek)et pedig mindazoknak ajánlom, akik érdeklődnek a város és a jármügyártás, illetve tágabb értelemben a települések és az ipar (a gazdaság) sikerei közötti összefüggések iránt.

\section{Irodalom}

Bakti M. (2002): Gödöllő, a sikeres város. Comitatus, 1-2., 27-36.

Baranyi B. (2000): Mátészalka, a sikeres város: igazi siker-e vagy csak reménykeltő kitörési kísérlet? Tér és Társadalom 1., 101-128.

Enyedi Gy. (1997): A sikeres város. Tér és Társadalom, 4., 1-7.

Kiss É. (1992): A helyi vezetés jellemzői a Közép-Tiszavidék településein. Alföldi Társadalom 3., 129-139.

Ludescher G. (2009): The role of local communities in the success of villages. Romanian Review of Regional Studies, 2., 51-58.

Mezeyné Varju E. (1998): Székesfehérvár - a vállalkozások sikeres színtere. Területi Statisztika, 1., 85-87.

Timár J., Velkey G. (szerk.) (2003): Várossiker alföldi nézőpontból. MTA RKK Alföldi Intézete, MTA Társadalomkutató Központ, Békéscsaba, Budapest

Váradi M. M. (1997): Solymár: az aranyfalu. Tér és Társadalom, 4., 45-68. 